\title{
KRITIK ATAS TANGGUNG JAWAB SOSIAL PERUSAHAAN DALAM BENCANA LUMPUR LAPINDO
}

\author{
Lutfi Amiruddin \\ Departemen Sosiologi Universitas Brawijaya \\ Email: amiruddin.lutfi@ub.ac.id
}

\begin{abstract}
In Lapindo mudflow disaster, the process of sale and purchase mechanism of sinking assets is legitimated by Presidential Decree 14/2007 (Perpres 14/2007), claimed by Lapindo as their social responsibility. In the discussion over the causes of the disaster, this scheme also raises controversy. If it was caused by an earthquake, why the company is willing to spend money to buy survivors' assetas as form of social responsibility? On the other hand, the mechanism made conflict among the survivors. I used qualitative method; using indepth interview, observation, and literature study. I chose some informants from different side to get various perspective, such as Lapindo and survivors, in order to get the corporate social responsibility narratively and its critics. Using the concept of governmentality of Foucault, I reveal the process of Corporate Social Responsibility (CSR) in the ecological crisis in Sidoarjo is only a way to cover the mistakes that have been made, not to recover the survivors' social and ecological conditions. The mechanism above implied to mudflow disaster management.
\end{abstract}

Keywords: Corporate social responsibility; Disaster; Lapindo case.

\begin{abstract}
ABSTRAK
Dalam bencana luapan lumpur Lapindo, skema jual beli aset warga yang tenggelam, yang terlegitimasi melalui Perpres 14/ 2007, diklaim oleh pihak Lapindo sebagai tanggung jawab sosial. Di tengah perdebatan terkait penyebab bencana, mekanisme ini juga menimbulkan kontroversi. Model tanggung jawab sosial ini justru menimbulkan pertanyaan baru. Kalau memang disebabkan karena gempa bumi, mengapa pihak perusahaan bersedia menghabiskan dana untuk melakukan jual beli dengan penyintas sebagai bentuk tanggung jawab sosial? Di lain pihak, mekanisme jual beli aset warga menimbulkan dampak berupa tercerai berainya ikatan sosial di antara penyintas. artikel ini ditulis dengan menggunakan metode kualitiatif; dengan teknik wawancara mendalam, pengamatan, dan studi literatur. Beberapa informan dipilih secara sengaja dari berbagai pihak seperti Lapindo dan penyintas untuk mendapatkan sudut pandang yang berbeda, untuk mendapatkan narasi terkait tanggung jawab sosial Lapindo dan kritik terhadapnya. Dengan menggunakan konsep governmentality Foucault, tulisan ini mengungkap proses tanggung jawab sosial perusahaan (Corporate Social Responsibility/ CSR) dalam setting krisis ekologis di Sidoarjo. Dalam kasus ini, tanggung jawab sosial perusahaan hanyalah merupakan instrumen untuk menutupi kecerobohan yang telah dilakukan, bukan memulihkan kondisi sosial ekologis penyintas. Mekanisme tanggung jawab sosial tersebut berimplikasi pada manajemen penanganan bencana lumpur.
\end{abstract}

Kata Kunci: Bencana; Kasus Lapindo; Tanggung jawab sosial perusahaan. 


\section{PENGANTAR}

Selama ini pemberitaan yang beredar di masyarakat umum terkait kasus Lapindo sebagian besar terkait dengan mekanisme pelunasan ganti rugi saja (baca: jual beli). Padahal di luar itu terdapat banyak masalah lain yang menjadi dampak dari bencana ini. Mekanisme pelunasan jual beli hanya satu masalah di antara banyak hal yang mengemuka akibat krisis ekologis ini. Beredarnya berita hanya sebatas pelunasan jual beli, seakan-akan masyarakat hanya disuguhi oleh penyelesaian yang sifatnya ekonomi saja. Tulisan ini berusaha menyingkap bahwa dalam bencana lumpur, skema jual beli justu dimanfaatkan pihak Lapindo untuk menutup-nutupi pengetahuan terkait bencana yang beredar. Melalui mekanisme ini, Lapindo mengklaim telah menjalankan tanggung jawab sosial perusahaan (Corporate Social Responsibility) CSR).

Untuk menuntaskan bencana luapan lumpur Lapindo, pemerintah menerbitkan sejumlah aturan, antara lain: yakni Kepres 13/ 2006, Perpres 14/2007, Perpres 48/ 2008, Perpres 40/2009, Perpres 68/2011, Perpres 37/2012, Perpres 33/2013, hingga yang terbaru Perpres 21/2017. Hampir semua peraturan presiden menegaskan tugas Badan Penanggulangan Lumpur Sidoarjo (BPLS), perluasan Peta Area Terdampak (PAT), dan model jual beli tanah dan bangunan yang tenggelam. Hanya pada Perpres 14/2007, pihak Lapindo berkewajiban membeli aset warga yang tenggelam dan menjadi landasan pelaksanaan tanggung jawab sosial perusahaan yang diemban oleh pihak Lapindo. Dalam pasal 15, antara lain disebutkan bahwa Lapindo Brantas harus membeli tanah dan bangunan penyintas yang tenggelam yang dimasukkan dalam Peta Area Terdampak 22 Maret 2007 dengan cara dicicil tanpa bunga, yang harus dilunasi setelah dua tahun disahkan peraturan tersebut (Republik-Indonesia, Peraturan Presiden Republik Indonesia Nomor 14 Tahun 2007 Tentang Badan Penanggulangan Lumpur Sidoarjo, 2007). Aset penyintas yang tenggelam yang masuk dalam Perpres 14/2007, dibeli oleh Lapindo, sedangkan seiring perluasan luapan lumpur, aset warga yang tenggelam dan masuk dalam perpres setelahnya ditanggung oleh APBN (Amiruddin, 2012:50).

Untuk lebih mengerucutkannya, dapat dilihat bagaimana pihak Lapindo berperan sebagai subjek pelaksana tanggung jawab sosial (Corporate Social Responsibility/ CSR) di tengah krisis ekologis melalui proses pembelian aset penyintas yang berada dalam PAT 22 Maret 2007 didasarkan pada Perpres 14/2007. Tanggung jawab jual beli tersebut diklaim sebagai upaya utama dalam tanggung jawab sosial perusahaan (Richards, 2011).

Gagasan jual beli aset, pertama kali berasal dari surat tertanggal 4 Desember 2006 dari pihak Lapindo Brantas Inc., ditujukan kepada Tim Nasional Penanggulangan Semburan Lumpur Sidoarjo (Timnas PLS) yang menyatakan bahwa proses jual beli merupakan "bentuk kepedulian sosial dan tanggung jawab moral". Surat tersebut menindaklanjuti pertemuan antara warga terdampak dengan pihak Lapindo Brantas Inc. pada 1 Desember 2006 (Surat Lapindo Brantas Inc, 2006).

Akan tetapi, yang perlu dikaji ulang meliputi: (1) apakah kepedulian sosial dan tanggung jawab moral Lapindo itu dapat dilakukan dengan cara jual beli? (2) Mengapa Lapindo mengambil peran dalam kepedulian sosial dan tanggung jawab moral melalui skema jual beli? Oleh karena itu, proses tanggung jawab sosial yang diambil Lapindo tidak dianalisis sebagai proses yang linear semata. Ada lingkar pengetahuan dan kekuasaan yang diproduksi di antara para aktor yang terlibat. Tanggung jawab sosial perusahaan yang diambil oleh pihak Lapindo, hanya merupakan mekanisme untuk menutup-nutupi kelalaiannya dalam proses produksi, bukan memulihkan kondisi sosial ekologis penyintas.

Tulisan ini bertujuan mengungkap narasi tanggung jawab sosial perusahaan dalam bencana lumpur Lapindo diSidoarjo. Tanggung jawab sosial dalam kondisi krisis ini tidak cukup dimengerti sebagai sebuah proses yang linear saja. Dikarenakan bencana lumpur telah masuk dalam pusaran politik dengan banyak kepentingan (Batubara dan Utomo, 2011: 139; Schiller dkk., 2008: 76). Di sisi lain, praktik CSR 
juga telah masuk ranah kepentingan politik (Kurtcu, 2014: 12). Dalam kasus bencana lumpur, Lapindo telah mengklaim bahwa proses jual beli adalah bentuk tanggung jawab sosial (Richards, 2011). Dengan menggunakan kerangka pemikiran Foucault, tulisan ini menelusuri proses tanggung jawab sosial dengan perspektif Lapindo, penyintas, dan pemerintah. Asumsinya adalah kekuasaan dan pengetahuan itu terkait erat. Keduanya juga tersebar di antara para aktor yang terlibat (Haryatmoko, 2010). Untuk itu, tanggung jawab sosial perusahaan berupa jual beli hanyalah suatu cara untuk menutupi kesalahan yang memang sudah dilakukan oleh perusahaan tambang ini, bahkan sebelum bencana terjadi.

Tulisan ini adalah bagian dari penelitian lapangan yang dilakukan penulis pada komunitas penyintas lumpur Lapindo sejak 2011. Metode penelitian yang dilakukan adalah kualitatif. Dengan menggunakan cara kerja kualitatif, didapatkan situasi alamiah dari subjek penelitian, yang berhubungan dengan pemahaman atas situasi yang dialaminya (Berg, 2001:3). Hal ini penting untuk membangun narasi tanggung jawab dari berbagai macam sudut pandang, dari pihak penyintas, Lapindo, dan pemerintah, juga merumuskan kritik terhadap skema tersebut. Tiap kelompok dalam metode penelitian bencana, perlu diperhatikan karena memiliki kepentingan masing-masing yang berbeda-beda (Drabek, 1970:332).

Penggalian data dilakukan dengan wawancara mendalam kepada tiga informan, pengamatan semi terlibat kepada dua informan, dan pengumpulan data sekunder. Wawancara dan pengamatan kepada informan terpilih dari pihak penyintas berasal dari Desa Besuki Wetan, Kecamatan Jabon, Desa Siring dan Renokenongo, Kecamatan Porong. Data dari penyintas ini digunakan untuk menelusuri data mengenai pemahaman penyintas terkait penyebab bencana. Wawancara juga diarahkan untuk menelusuri pemahamahan informan terhadap tanggung jawab sosial Lapindo, berupa pembayaran uang jual beli yang diamanatkan oleh Perpres 14/2007. Harapannya, tergambarkan bagaimana sebenarnya bentuk tanggung jawab sosial yang diemban Lapindo dari perspektif penyintas sebagai aktor yang terlibat, penyintas juga memiliki pengetahuan atas apa yang dirasakan dan diberlakukan kepadanya.

Di lain pihak, wawancara juga dilakukan kepada salah satu CEO anak perusahaan Lapindo Brantas, yang juga seorang dosen di universitas negeri di Jawa Timur. Data dari pihak perusahaan ini juga digunakan untuk membangun narasi tanggung jawab sosial perusahaan dari perspektif organisasi perusahaan tersebut. Pada bagian ini, data primer banyak dilengkapi dengan penelusuran dan studi dokumen sebagai sumber data sekunder. Data ini dimanfaatkan untuk mengungkap peran tanggung jawab sosial oleh pihak Lapindo, seperti, surat-surat resmi, dan Majalah Solusi terbitan Lapindo. Sedangkan dari pihak pemerintah sayangnya hanya dapat dimanfaatkan data sekunder berupa naskah undang-undang dan peraturan presiden. Sebab, pihak pemerintah, khususnya BPLS, tidak pernah memberikan jawaban atas permintaan wawancara yang disampaikan oleh penulis. Untuk alasan keamanan, semua nama narasumber dalam tulisan ini disamarkan dalam inisial.

\section{PEMBAHASAN}

\section{Tanggung Jawab Sosial Perusahaan Kebaikan Hati dalam Proses Jual Beli}

Perusahaan berkewajiban menjalankan tanggung jawab sosial atas dampak yang ditimbulkan karena aktivitas produksinya sehingga muncul konsep Corporate Social Responsibility (CSR), yang didefinisikan sebagai:

"[A]s the ways in which a business seeks to align its values and behaviour with those of its stakeholders. The stakeholders of the business include the workers, customers, suppliers, government, interest groups (such as environmental groups) and wider societal interests on whom the operations of the business may have an impact." (Mallin, 2009: 1).

Sedangkan, aturan mengenai tanggung jawab sosial perusahaan di Indonesia telah tertulis melalui Undang-Undang Republik Indonesia Nomor 25 tahun 2007 tentang Penanaman Modal. Pada pasal 15 menyatakan 
bahwa tanggung jawab yang ada pada perusahaan atas konsekuensi proses produksi dalam rangka menciptakan hubungan yang harmonis antara perusahaan dengan masyarakat dan lingkungan sekitarnya (RepublikIndonesia, Undang-Undang Republik Indonesia Nomor 25 Tahun 2007 tentang Penanaman Modal, 2007). Akan tetapi, kondisi tersebut dideskripsikan jika situasi berada dalam situasi "normal". Hal ini berbeda dalam kondisi bencana merupakan situasi di luar keadaan normal pada umumnya sehingga bencana dapat pula dimaknai sebagai peristiwa di luar rutinitas masyarakat (Kreps \& Drabek, 1996).

Sejak pertama kali menyembur pada Mei 2006, respon penanganan telah dilakukan oleh Lapindo. Bukti dari proses ini adalah dilayangkannya surat tertanggal 4 Desember 2006 dari pihak Lapindo Brantas Inc. ditujukan kepada Timnas PLS. Surat ini penting karena berisi pernyataan Lapindo bahwa sebagai bentuk "kepedulian sosial dan tanggung jawab moral" dengan membeli tanah dan rumah penyintas yang tenggelam. Nilainya antara lain: tanah pekarangan sebesar $\mathrm{Rp} 1.000 .000,00 / \mathrm{m}^{2}$, sedangkan bangunan sebesar Rp1.500.000,00/ $\mathrm{m}^{2}$, dan tanah sawah sebesar Rp20.000,00/ m² (Surat Lapindo Brantas Inc, 2006). Laporan yang dibuat oleh pihak Lapindo juga menunjukkan hal yang sama, yaitu tanggung jawab sosial itu diambil oleh Lapindo dengan cara membeli bangunan dan tanah yang tenggelam (Richards, 2011: 77). Surat 4 Desember 2006 tersebut kemudian mendapatkan legitimasi dari pemerintah empat bulan kemudian, yaitu melalui terbitnya Perpres 14/2007. Pada akhirnya penyelesaian dengan cara jual beli menjadi sah sebagai upaya tanggung jawab pihak Lapindo. Dalam Perpres 14/ 2007 pasal 15, pihak Lapindo berkewajiban membeli bangunan dan tanah yang tenggelam dengan cara dicicil.

Dengan diterbitkannya Perpres 14/ 2007, maka jual beli diklaim sebagai bentuk tanggung jawab sosial Lapindo dalam menghadapi krisis. Untuk menghadapi krisis menurut Kriyantoro bahwa sebenarnya pihak Lapindo tidak memiliki perencanaan dan persiapan public relation yang matang. Maka di titik inilah mereka menyebutkan bahwa semburan lumpur adalah bencana alam (Kriyantono, 2012: 218). Untuk memperkuatnya, "pihak Lapindo mengundang pakar geologi luar negeri, yaitu Sergey Kadurin, untuk memberikan legitimasi ilmiah" (Karib, 2012: 69). Sedangkan, putusan Mahkamah Agung 14 Desember 2007 juga memperkuat wacana bahwa semburan lumpur disebabkan oleh gempa bumi Yogyakarta pada 27 Mei 2006, bukan karena kesalahan pengeboran (Kriyantono, 2011: 6). Maka dari itu, yang dilakukan oleh pihak Lapindo tersebut hanya upayanya untuk memperbaiki reputasi perusahaan, bukan menjawab kebutuhan penyintas (Kriyantono, 2011: 2). Perbaikan reputasi ini kemudian terimplementasi melalui mekanisme penanganan bencana yaitu jual beli.

Akan tetapi, pada kenyataannya dalam proses awal mekanisme jual beli, dijalankan dengan cara koersif. Catatan Karib mengatakan bahwa beberapa penyintas yang rumah dan tanahnya tenggelam di awal semburan dari Desa Jatirejo karena akan dibangun sebagai tanggul, mereka harus rela menjual rumah dan tanahnya dengan cara paksaan, dengan melibatkan pihak militer untuk mengintimidasi warga agar mau menjual tanah dan rumahya (Karib 2012: 66-67). Setelah peristiwa itu, kemudian dikeluarkanlah Perpres 14/ 2007 yang di dalamnya mewajibkan pihak Lapindo untuk membeli rumah dan tanah yang tenggelam. Maka dari itu, logika jual beli ini kemudian menjadi wacana dominan dalam penyelesaian masalah penyintas lumpur Lapindo. Di saat yang sama, terdapat penggiringan wacana publik tentang penyebab bencana. Dengan menggunakan argumen geolog, seperti temuan Mazzini dan kawankawan (Triggering and Dynamic Evolution of The Lusi Mud Volcano, Indonesia, 2007) pihak Lapindo selalu menyatakan bahwa penyebab semburan lumpur adalah karena gempa Yogyakarta 27 Mei 2007.

Di tengah pembayaran jual beli, dilakukan pula upaya perbaikan reputasi melalui media yang diproduksi oleh Lapindo, salah satunya yaitu Majalah Solusi. Dalam edisi 35, 22-28 Juli 2008 mengantarkan berita bahwa makanisme 
jual beli aset yang dilakukan merupakan buah kebaikan hati dari keluarga Bakrie. Keluarga pemilik saham ini dinilai memiliki hati yang mulia karena memang bencana yang terjadi dianggap bukan karena aktivitas pengeboran, yang artinya bukan karena kesalahannya. Jual beli aset warga dinilai merupakan cara yang tepat (Editorial, Bakrie Factors, Majalah Solusi Edisi 35, 22-28 Juli 2008). Pada edisi lain majalah Solusi juga memaparkan bahwa jual beli aset tenggelam didefinisikan sebagai "di balik musibah ada berkah". Dikarenakan melalui bencana ini, penyintas dianggap justru mengalami perubahan yang lebih baik (Editorial, Pilihan, Majalah Solusi Edisi 29, 1016 Juni 2008). Jadi, logika yang dibangun adalah bahwa pihak perusahaan tetap bertanggung jawab meskipun luapan lumpur bukan terjadi karena kesalahannya.

Akan tetapi, yang harus dipertanyakan adalah, apakah jual beli itu adalah bentuk kebaikan hati? Bukankah jual beli itu bussiness as usual? Maka, hal ini sebangun dengan argumen yang dibangun Kriyantono (2011), bahwa yang dilakukan pihak Lapindo untuk memperbaiki reputasi, tetapi dengan cara menyebarkan wacana "kebaikan hati, meskipun bukan kesalahannya". Kebaikan hati ini diimplementasikan melalui tanggung jawab sosial perusahaan, dengan cara jual beli tanah dan bangunan yang tenggelam.

Upaya ini mirip dengan temuan Welker (2009:2-3) tentang penyebaran wacana moral berupa kebaikan hati, melalui praktik CSR Newmont. Menurutnya, agar perusahaan tetap dapat berproduksi, maka program CSR Newmont harus bisa dijalankan. Salah satu yang menjadi catatan penting Welker adalah bagaimana kewajiban moral itu dijalankan dengan tindakan kekerasan bagi komunitas yang menentang keberadaan Newmont. Mereka yang menjalankan CSR sekaligus tindak kekerasan antara lain elite lokal, preman, hingga guru sekolah. Akan tetapi, ada perbedaan mendasar antara temuan Welker dengan artikel ini. Bila Welker menyatakan bahwa tanggung jawab sosial Newmont, dijalankan agar proses produksi tetap berjalan, maka artikel ini justru menunjukkan bahwa tanggung jawab sosial justru baru muncul ketika terjadi krisis ekologi berupa bencana semburan lumpur. Setting bencana menjadi latar menarik, yang dapat membedakan dengan situasi "normal". Seandainya saja tidak ada peristiwa semburan lumpur, dapat jadi mekanisme tanggung jawab sosial berupa jual beli aset, tidak pernah dijalankan.

Pada akhirnya, tanggung jawab sosial berupa proses jual beli mendapatkan legitimasi untuk dilakukan melalui Perpres 14/2007. Peraturan ini akhirnya menggiring penyintas lumpur bersedia untuk masuk dalam skema jual beli, yang justru gagasannya berasal dari pihak Lapindo. Dengan "kebaikan hati dalam proses jual beli" ini, seakan-akan penyintas telah memasuki penyelesaian ideal dalam penanganan krisis ekologis.

Perihal skema jual beli dapat diterima dan mendapat legitimasi dari peraturan presiden, dapat dilihat dengan perspektif yang ditawarkan Foucault. Dengan menyitir pendapat Kant, Foucault melihat bahwa di zaman pencerahan ditawarkan sebuah "way out", yang memiliki ciri pembebasan atas manusia. Akan tetapi di sisi lain, pencerahan ini juga menggiring manusia untuk menerima dan menuruti otoritas manusia lain (Foucault, 1984: 35). Hal ini pula sejalan dengan ilustrasi Foucault terkait percakapan antara seorang dokter jiwa dengan pasiennya. Si pasien menangis karena dia dipaksa oleh dokter tersebut untuk mengakui kegilaannya (Foucault, 1997: 172). Dengan logika dokterpasien itu, "kebaikan hati jual beli" inilah yang dipaksakan oleh Lapindo agar diberlakukan bagi penyintas.

Kata Foucault, mungkin Kant lupa, bahwa manusia itu memiliki sisi subjektif. Dan mengikuti pencerahan sebagai kewajiban, menurut Foucault juga kurang tepat. Menurut Foucault, manusia memiliki daya "dare to know", hasrat untuk mendapatkan pengetahuan (1984: 35). Mengenai hal ini salah seorang informan berinisial $\mathrm{Pt}$, pernah bercerita sekaligus mempertanyakan proses jual beli yang dialaminya dengan pihak Lapindo. Dia berasal dari Desa Renokenongo yang telah tenggelam dan kini telah tinggal di resettlement. 
"Dia mengandaikan proses jual beli ini seperti peristiwa kecelakaan dijalan. Ketika mengendarai motor, tiba-tiba ada mobil yang menabraknya dari belakang. Dia ditabrak oleh mobil tersebut, meski tidak melanggar aturan lalu lintas apapun. Untuk mempertanggungjawabkan, pengendara mobil tidak memberikan biaya berobat atau perbaikan motor, tetapi malah mau membeli motor yang telah rusak itu. Dia pun mempertanyakan, kenapa prosesnya seperti ini? Apa yang sebenarnya terjadi? Apa yang sebenarnya diinginkan pengendara mobil? Apakah dengan membeli, dianggap sebagai bentuk kebaikan hati?"

Apakah benar jual beli adalah bentuk kebaikan hati? Bagi Karib (2012), jual beli adalah proses land exclusion, sebuah proses pemisahan warga dari tanahnya, dan hal tersebut akan mendukung masa depan perusahaan. Dalam prosesnya sebenarnya Lapindo tengah mengambil alih tanah yang semula dimiliki warga. Atau bagi Kriyantono (2011), sebagai tanggung jawab sosial, jual beli adalah proses memperbaiki reputasi perusahaan di masa depan. Jika temuan kedua penulis tersebut lebih berdimensi "masa depan perusahaan", maka tulisan ini, mendasarkan penelusuran pada "masa lalu korporasi". Maka, dapat dikatakan bahwa melalui wacana tanggung jawab sosial atas dasar kebaikan hati, sebenarnya pihak Lapindo sedang menutupi kelalaian yang sudah diperbuat. Sebab, Kalau toh bukan kesalahan pengeboran dan Lapindo bebas dari jerat hukum, kenapa mereka mau menghabiskan uang untuk membeli aset warga?

\section{Menutupi Penyebab Bencana, Menutupi Kesalahan Perusahaan}

Terdapat dua teori umum dari para geolog untuk menjawab penyebab semburan lumpur. Pendapat pertama didapatkan analisis bahwa lumpur yang menyembur disebabkan karena kesalahan pengeboran (Akbar, 2007; Davies dkk., 2008). Temuan ini bahkan diperkuat oleh laporan Adams bahwa semburan lumpur terjadi karena tidak dipasangnya casing saat aktivitas pengeboran berlangsung (Adams, 2006). Teori ini berimplikasi pada siapa sebenarnya yang lalai pada insiden banjir lumpur di Sidoarjo. Pendapat kedua menyatakan bahwa semburan lumpur disebabkan karena gempa bumi yang melanda Yogyakarta pada dua hari sebelumnya, 27 Mei 2006, dan bukan dipicu oleh aktivitas pengeboran (Mazzini, et al., 2007). Pendapat yang kedua inilah yang selalu dipakai Lapindo untuk mengungkapkan seolah-olah bencana yang terjadi bukanlah kesalahan pengeboran, melainkan bencana alam. Bahkan karena semburan lumpur itu, pihak Lapindo juga merupakan korban karena peralatan pengeborannya juga tenggelam (Amiruddin, 2012: 49). Pendapat Mazzini $d k k$, tersebut juga digunakan untuk memperkuat pendapat bahwa meskipun tidak melakukan kesalahan, pihak Lapindo memiliki kebaikan hati untuk bertanggung jawab secara sosial.

Untuk itu, maka dalam proses penelitian, perlulah ditelusuri pendapat dari penyintas tentang pemahaman mereka terhadap teori geologi ini:

\begin{abstract}
"Adalah seorang informan berinisial Ir yang juga mantan petani yang dari Desa Besuki Timur yang pertama kali menyadarkan peneliti atas ide dasar tulisan ini. Dalam sebuah diskusi di tahun 2011 yang lalu, kami membicarakan tentang sawahnya tenggelam karena lumpur. Kami juga membicarakan tentang hampir semua kenangan di desanya hilang akibat bencana ini. Keluh kesahnya tidak hanya masalah pekerjaan yang hilang, tetapi juga masalah udara, air, tanah yang tercemar, yang membuat orang jadi berpenyakit, serta hubungan antar tetangga yang penuh dengan konflik.
\end{abstract}

Mengenai teori geologi, baginya itu tidak penting. Dia tidak mempermasalahkan perdebatan temuan para geolog itu. Yang dia pertanyakan adalah kalau toh memang bukan kesalahan pengeboran, desanya tidak akan tenggelam kalau tidak ada perusahaan pengeboran didirikan di wilayah desanya."

Menelusuri pengetahuan warga tentang teori geologi ini menjadi menarik. Sebab, hal ini dapat membuka berbagai macam perspektif tentang penyebab bencana dan proses pertanggungjawaban dari pihak perusahaan. Dari informan Ir, terungkap bahwa memang perusahaan pengeboran ini dibangun di tengah pemukiman padat huni tanpa keterbukaan informasi. Warga tidak mengetahui jika 
di sekitar pemukiman mereka terdapat perusahaan tambang yang berdiri. Informasi awal yang beredar yang berdiri di tengahtengah kampung mereka bukanlah perusahaan pengeboran, melainkan peternakan. Warga baru mengetahui kalau yang berdiri di desanya adalah perusahaan ekstraktif justru setelah ada semburan lumpur (Santoso, 2007: 5).

Hal inilah sebenarnya mengapa tanggung jawab sosial yang diambil Lapindo selalu dibingkai dalam "kebaikan hati keluarga Bakrie". Sebab dari sebelum melakukan aktivitas pengeboran pun, warga telah disuguhi dengan kebohongan mengenai berdirinya perusahaan migas ini. Tanggung jawab sosial perusahaan dengan cara jual beli merupakan cara untuk menutup segala kemungkinan alternatif informasi bagi masyarakat luas bahwa terdapat ketertutupan informasi atas pendirian perusahaan tambang di tengah pemukiman warga. Tanggung jawab sosial berupa jual beli oleh Lapindo, hanyalah upaya menutupi kebohongan demi kebohongan informasi, dan kesalahan-kesalahan yang dilakukan sebelumnya. Wacananya seolaholah jika pihak perusahaan berbuat baik, maka kesalahan di masa lalunya akan tertutupi. Sistem jual beli kemudian menjadi rezim kebenaran dalam proses penanganan bencana lumpur, apalagi ketika mendapat pengesahan dari Perpres 14/ 2007.

Sebuah rezim kebenaran (regime of truth) dipahami sebagai sesuatu yang memunculkan sebuah "kebenaran", yang sebaliknya pula menghubungkannya dengan sesuatu "kesalahan" (error). Akan tetapi, kesalahan" dianggap tetap tidak pernah ada. Yang selalu dimunculkan "kebenarannya". Rezim kebenaran ini semakin mendapatkan pengakuannya, ketika dilaksanakan oleh para aktor yang terlibat (Foucault, 2004: 19). Maka jual beli dalam kasus Lapindo, dibangun sebagai mekanisme yang seolah-olah benar, dianggap sebagai rezim kebenaran. Sedangkan mekanisme lain, dianggap bukan sebagai kebenaran. Ketika rezim kebenaran tersebar, maka secara tidak langung pula "kesalahan" akan tertutupi, dan bahkan dianggap tak pernah ada.
Sementara itu, bagaimana dengan penyintas yang dikenai tanggung jawab sosial itu? Kutipan hasil wawancara informan $\mathrm{Pt}$ berikut ini, dapat menggambarkan bagaimana upaya tanggung jawab sosial perusahaan, justru membuat rusaknya ikatan sosial di antara warga:

\begin{abstract}
"Dengan lancar pula dia menceritakan bahwa bencana lumpur Lapindo ini telah membuat hubungan antar tetangga pecah. Setelah adanya bencana ini, terdapat banyak konflik horizontal antara anggota keluarga, juga antar tetangga. Salah satu pemicunya adalah masalah jual beli aset warga yang tenggelam, berupa tanah, rumah, dan sawah. Karena bencana ini ada banyak orang yang menjadi pengangguran. Belitan ekonomi ini memicu perebutan uang hasil jual belinya, iri dengki di antara saudara sedarah, sesama tetangga."
\end{abstract}

Merujuk pada pendapat Oliver-Smith tentang masyarakat yang ada dalam tahap pasca bencana, ternyata masih berpotensi masuk dalam bencana baru, meskipun telah berada di pemukiman kembali (Oliver-Smith, 1991:13). Data yang menggambarkan konflik horizontal tersebut menunjukkan bahwa proses jual beli justru mengantarkan para penyintas masuk dalam situasi konflik di antara sesamanya. Penyelesaian bencana dengan mekanisme transaksional tidak menjawab kebutuhan penyintas dalam hal pemulihan sosial dan budaya. Seolah-olah skema jual beli adalah pilihan terakhir yang justru membuat penyintas masuk dalam risiko bencana sosial yang baru.

Ketika relasi di antara aktor terfokus pada masalah jual beli, justru dampak pada sektor ekonomi terabaikan. Laporan McMichael menunjukkan bahwa bencana lumpur mengganggu sektor ekonomi regional Jawa Timur di sektor bisnis sebesar Rp28.3 triliun, dengan rincian berupa Rp8.3 triliun kerugian karena terganggunya infrastruktur, Rp5.8 triliun kerugian nilai produk khas Sidoarjo (produk perikanan dan industri kecil), dan Rp14.2 triliun kerugian tak langsung pada bisnis Jawa Timur, hanya di tahun ke dua semburan (McMichael, 2009: 76). Lalu bagaimana dengan kondisi ekonomi warga? Pada tahun pertama semburan misalnya, telah mengakibatkan 1.873 
jiwa menjadi penganggur (Batubara \& Utomo, 2011: 40).

Adanya luapan lumpur juga menyebabkan pencemaran lingkungan dan berdampak bagi kesehatan manusia. Putri dan Yudhastuti menyatakan bahwa kandungan besi (Fe) pada air tanah di wilayah desa sekitar semburan memicu kecenderungan penyakit seperti diare, mual, muntah, dan nyeri perut (Putri \& Yudhastuti, 2013). Sebelumnya, hasil penelitian Wahana Lingkungan Hidup Jawa Timur (Walhi Jatim) menunjukkan kecenderungan yang lebih mengerikan, yaitu kandungan senyawa logam berat bernama polycyclic aromatic hydrocarbon (PAH) yang melebihi ambang batas normal di beberapa lokasi dekat dengan semburan, berpotensi menjadi senyawa pemicu sel kanker (Walhi Jawa Timur, 2008).

Data di atas hanya mencerminkan permasalahan ekonomi pada awal-awal bencana saja. Dapat diprediksikan masalah ekonomi, baik di level warga hingga regional akan terganggu dalam beberapa tahun mendatang. Demikian pula dengan kerusakan ekologis akibat pencemaran akan terus mengancam warga yang masih tinggal di sekitar lokasi semburan. Dapat dipastikan, pencemaran lingkungan dan ancaman bagi kesehatan akan terus berlanjut dalam beberapa tahun ke depan karena upaya penghentian semburan tak lagi dilakukan.

\section{Memahami Relasi Antar Aktor dalam Tanggung Jawab Sosial Lapindo}

Bagaimana logika tanggung jawab sosial perusahaan, dalam kasus Lapindo ini bisa muncul? Kurtcu (2014), menegaskan bahwa CSR bukan semata proses yang melibatkan struktur ekonomi saja, melainkan juga politik. Kurtcu menambahkan bahwa dalam praktik CSR, berjalan logika seperti halnya yang dibangun oleh Foucault, yaitu governmentality. Governmentality merupakan"the ensemble formed by the institutions, procedures, analyses and reflections, the calculations and tactics" that shapes a specific form of exercising power (Kurtcu, 2014: 10). Dalam governmentality, juga berlaku the technologies of power dan technologies of self. Technologies of power didefinisikan sebagai sesuatu yang menentukan individu dapat mengikuti mekanisme kekuasaan aktor yang lain. Dalam proses ini, individu dianggap sama, sesuatu yang objektif. Sedangkan technologies of self merupakan mekanisme individu untuk masuk dalam situasi seperti kebahagiaan, kebijaksanaan, kemurnian, dan sebagainya. Hubungan di antara kedua macam technologies itu disebut sebagai governmentality (1988:1). "Government", kata Lemke, tidak hanya terkait dengan sesuatu yang bernuansa politik, melainkan juga dalam keseharian manusia, seperti pendidikan, agama, dan penanganan medis (Lemke, 2001:191). Hal ini berlaku pula pada model tanggung jawab sosial dalam penyelesaian bencana Lapindo, karena dampaknya memang berlaku dalam kehidupan keseharian penyintas.

Melalui tulisan Plato, Foucault menggarisbawahi pernyataan "take care of yourself" and "know yourself", bahwa seseorang yang bisa menjaga dirinya, dia memahami dirinya pula (Foucault, 1988:1). Yang artinya bahwa jika seseorang dapat memiliki keberdayaan atas diri, maka dia akan dapat mengenali apa kebutuhannya, kemauan, dan segala hal yang berkaitan dengan kediriannya. Dalam konteks bencana lumpur, keberdayaan dan kendali atas diri penyintas diambil alih oleh pihak Lapindo melalui proses jual beli. Seakan-akan, Lapindo lah yang memiliki kuasa atas pilihan warga agar mampu bertahan hidup. Dengan menggunakan logika "medical model", dia menunjukkan bahwa dalam kehidupan, sesorang harus bisa bagi dirinya sendiri, "one must become the doctor of oneself" (Foucault, 1988:2). Pilihan mandiri yang dimiliki oleh penyintas menjadi sangat tidak berarti mana kala Lapindo sejak awal bencana, berperan seolah menjadi dokter. Jadi, dari situasi ini, tidak ada lagi "one must become the doctor of oneself" karena yang berperan menjadi penyembuh seolah-olah adalah pihak Lapindo. Mekanisme jual beli kemudian dianggap sebagai cara yang masuk akal di antara pilihan-pilihan yang lain, apalagi ketika Perpres 14/ 2007 memberikan legitimasi atas proses tersebut. Karib (2012) menemukan bahwa jual beli pada akhirnya diterima oleh 
penyintas sebagai mekanisme penyelesaian berlangsung sejak 10 bulan awal bencana.

Di lain pihak, mekanisme jual beli juga menciptakan konflik horizontal di antara penyintas Lapindo (Amiruddin L. , 2012; Utomo \& Batubara, 2009). Konflik horizontal ini merupakan bagian dari proses technology of self. Sebab "jika saja pengetahuan atas diri memegang peran penting dalam'penyembuhan diri', maka hal ini berdampak pada hubungan dengan manusia yang lainnya." (Foucault, 1988:2). Hal ini dapat tergambarkan melalui hubungan antartetangga yang menjadi kian renggang dan bahkan terjadi konflik horizontal. Penyebabnya adalah penyintas diperkenalkan pada mekanisme yang memang "tidak untuk menyembuhkan dan mengenal diri mereka sendiri".

Dalam mekanisme penyelesaian bagi penyintas melalui Perpres 14/2007, diterapkan skema jual beli. Lapindo berperan sebagai pembeli aset, sementara penyintas adalah penjualnya. Dalam transaksi antara penjual dan pembeli, posisi keduanya dianggap setara, yang pada gilirannya mampu menyamarkan "siapa yang bersalah". Di saat yang sama, jual beli juga mencerminkan bentuk governmentality, sebuah mekanisme, taktik, dan strategi yang mempu mengoperasionalkan kekuasaan (power) dari aktor satu kepada yang lain (Kurtcu, 2014:10). Aktor utama, yaitu Lapindo dengan wacana berupa "kebaikan hati dalam proses jual beli", mampu menciptakan skema jual beli dan kemudian justru mendapat legitimasi peraturan presidan.

Dalam prosesnya, yang dipentingkan penyintas adalah surat tanah, rumah, dan sawah. Mekanisme ini membuat penyintas tidak benar-benar memahami kebutuhan mereka sendiri, seperti pekerjaan, kesehatan keluarga, dan pendidikan anak. Mereka hanya mementingkan bagaimana memenuhi dan menyediakan syarat legal aset mereka saja, seperti sertifikat tanah, pethok $D$, atau letter C. Di saat yang sama, penyintas juga tidak lagi peduli dengan kondisi lingkungan dan solidaritas antartetangga. Seolah, semakin cepat mereka menyiapkan bukti legal untuk memperlancar jual beli, semakin cepat pula mereka keluar dari situasi krisis, dan semakin logis pula skema jual beli diterima sebagai regime of truth (rezim kebenaran), dalam penyelesaian bencana industri ini.

Dari gambaran relasi antaraktor di atas, pada gilirannya berimplikasi pada bagaimana model manajemen bencana ini. Terdapat dua hal penting yang perlu digarisbawahi; pertama, masalah jual beli antara pihak Lapindo dengan korban dari enam desa yang masuk dalam Peta Area Terdampak (PAT) 2007 menunjukkan perbedaan perlakuan dengan Undang-Undang 24/2007 tentang Penanggulangan Bencana. Dalam undang-undang tersebut, pada pasal 26 menyebutkan bahwa penyintas berhak mendapatkan ganti rugi (Republik-Indonesia, Undang-Undang Republik Indonesia Nomor 24 Tahun 2007 tentang Penanggulangan Bencana, 2007). Jadi perlakuan atas mereka yang dianggap sebagai penyintas bukanlah jual beli. Maka konsekuensinya adalah tidak ada pemindahan hak milik aset yang terkena bencana. Sebaliknya, dalam kasus bencana lumpur, ada pemindahan hak milik. Rumah dan tanah yang semula dimiliki oleh warga, menjadi milik Lapindo yang dianggap sebagai tanggung jawab sosial perusahaan.

Kedua, adalah ketika penyelesaian bagi penyintas bencana industri ini berupa proses transaksional, maka sebagai penjual, penyintas hanya ingin asetnya segera terbeli. Dalam tiga tahun pertama bencana, jamak diketahui penyintas, Lapindo, dan pemerintah, hanya berfokus mementingkan kelengkapan bukti kepemilikan tanah. Maka dari itu, tidak pernah ada data berapa jumlah penyintas, rentang usia, jenis kelamin, persebaran resettlement, dan data dasar lainnya, baik yang dikeluarkan oleh pemerintah melalui BPLS, maupun dari pihak Lapindo. Yang selalu muncul menjadi wacara publik, hanyalah jumlah berkas aset warga yang lunas maupun yang belum terbayar. Sumber daya lahan yang melekat dengan nilainilai kehidupan sehari-hari masyarakat desa, dipandang hanya sebagai aset ekonomi, bukan ruang sosial budaya yang kompleks. Inilah titik ketika nilai kemanusiaan disingkirkan lalu digantikan dengan lembaran sertifikat aset dalam penanganan bencana industri. 
Lalu bagaimana relasi antar aktor pada bencana industri di belahan dunia lainnya? Contohnya adalah bencana kecelakaan reaktor nuklir di Harrisburg dan Chernobyl. Michael Faure menjelaskan bahwa para korban terdampak dua bencana nonalam tersebut diberikan kompensasi oleh perusahaan operator nuklir untuk mengganti kerugian akibat bencana berdasarkan hukum internasional yaitu Konvensi Paris dan Vienna tentang Pertanggungjawaban dalam Kecelakaan Nuklir, yang telah diratifikasi oleh negara-negara yang mengikuti konvensi tersebut (Faure, 1995:21). Patut diperhatikan adalah bahwa Faure mengakuai bahwa kompensasi ekonomi bukanlah tujuan akhir (Faure, 1995:27). Dengan kata lain, kompensasi ekonomi hanya berusaha untuk mengganti kerugian ekonomi yang diderita para penyintas untuk sementara waktu. Di sisi lain, Sugarman memberikan beberapa saran mengenai pemberian kompensasi bagi penyintas bencana. Pemerintah memiliki peran sentral dalam kompensasi, baik dalam bencana alam (natural) maupun buatan manusia (man made) (Sugarman, 2006). Situasi yang berbeda terjadi pada kasus Lapindo. Alih-alih memberikan kompensasi bagi penyintas, yang terjadi justru Lapindo menjadikan mereka sebagai mitra jual beli yang disahkan pemerintah.

Dalam bencana lumpur Lapindo, permasalahan kerusakan lingkungan dan keselamatan warga tak pernah menjadi perhatian serius. Dari sisi Lapindo karena telah melakukan proses jual beli, seolah-olah terbebas dari kewajiban pemulihan lingkungan dan keselamatan penyintas. Sedangkan, pemerintah seakan membiarkan perusahaan tambang ini karena telah mencemari lingkungan dan belum melunasi cicilan jual beli. Keberhasilan menegakkan rezim kebenaran berupa tanggung jawab sosial perusahaan ternyata semakin meluas, tak hanya dalam penanganan bencana, tetapi juga pada proses produksi yang dilakukan perusahaan migas ini. Rezim kebenaran ini masih akan berlanjut, mana kala terlihat dalam kasus rencana pengeboran Lapindo di wilayah lain di Kabupaten Jombang, Jawa Timur. Dengan dalih melaksanakan proyek nasional untuk memenuhi kebutuhan migas, perusahaan pengeboran Lapindo Brantas berencana melakukan aktivitas produksi di wilayah padat huni yang mengancam keselamatan kehidupan warga (Amiruddin, 2018).

\section{SIMPULAN}

Dalam bencana lumpur Lapindo, wacana tanggung jawab sosial hanyalah mekanisme penutupan informasi yang tak pernah terungkap sebelumnya. Seakan-akan pihak Lapindo telah bertanggung jawab dalam krisis ekologis di Sidoarjo. Kedok ini menjadi semakin kentara ketika pihak Lapindo membungkusnya dengan wacana "kebaikan hati dalam proses jual beli" pemilik perusahaan. Model penyelesaian ini kemudian mendapatkan jalan yang semakin lapang melalui peraturan presiden, yang pada akhirnya mampu menciptakan rezim kebenaran bagi penyelesaian penyintas bencana lumpur. Justru ini adalah pintu masuk analisis bahwa tanggung jawab sosial tersebut hanyalah upaya menutupi kebusukan industri ekstraktif hidrokarbon di wilayah padat huni, secara khusus dalam bencana semburan lumpur.

Tulisan ini hanyalah bagian kecil yang membahas tanggung jawab sosial Lapindo berupa model jual beli saja. Ada banyak hal yang belum terungkap dari kasus ini, seperti pemulihan kondisilingkungan dan keselamatan warga yang tidak pernah mendapatkan penanganan serius, baik oleh pihak Lapindo maupun pemerintah. Bahkan, pada Desember 2014, muncul gagasan dari pemerintah untuk memberikan dana talangan bagi PT Minarak Lapindo Jaya agar dapat melunasi cicilan jual beli yang dilakukannya. Sebaliknya pula, tak pernah ada wacana mengenai sanksi bagi pihak Lapindo yang belum juga melunasi cicilan jual beli sebagaimana diamanatkan Perpres 14/2007 yang telah jatuh tempo. Oleh karena itu, kajian-kajian baru harus tetap dilakukan untuk membuka wacana bahwa bencana lumpur Lapindo belum tuntas hanya dengan penyelesaian jual beli saja. 


\section{DAFTAR PUSTAKA}

Adams, N. 2006. Causation Factors for The Banjar Panji No.1 Blowout. Report as Peer Consulting Services Agreement Causation Factors for The Banjar Panji No.1 Blowout to PT Medco EEP Indonesia. Sidoarjo: Unpublished.

Akbar, A. A. 2007. Konspirasi di Balik Lumpur Lapindo, Dari Aktor Hingga Strategi Kotor. Yogyakarta: Galangpress.

Amiruddin, L.2012. Solidarity ofLapindoMudflow Victims in Resettlements. Yogyakarta: Management of Infrastructure and Community Development, Sekolah Pascasarjana, Universitas Gadjah Mada.

Amiruddin, L. 2018. korbanlumpur.info. Diakses pada Juli 23, 2018. http://korbanlumpur.info/2018/04/penolakanwarga-atas-rencana-pengeboranlapindo-di-jombang-sebuah-reportasesingkat-dan-komentar/

Batubara, B., \& P. W. Utomo. 2011. Kronik Lumpur Lapindo, Skandal Bencana Industri Pengeboran Migas di Sidoarjo. Yogyakarta: Insist Press.

Berg, B. L. 2001. Qualitative Research Methods for The Social Sciences. $4^{\text {th }}$ ed. Boston: Pearson Education Inc.

Davies, R. J., Brummb, M., Manga, M., Rubiandini, R.,Swadbrick, R., \& Tingay, M. 2008. “The East Java Mud Volcano (2006 to Present): An Earthquake or Drilling Trigger?". ScienceDirect, Journal Earth and Planetary Letters.

Drabek, T. E. 1970. Methodology of Studying Disaster, Past Patterns and Future Possibilities. American Behavioral Scientist, 13(3): 331-343.

Editorial. 10-16 Juni 2008. Pilihan. Majalah Solusi Edisi 29. Surabaya: Majalah Solusi .

Editorial. 2008. "Bakrie Factors". Majalah Solusi Edisi 35. Surabaya: Majalah Solusi.

Editorial. 22-28 Juli 2008. Bakrie Factors. Majalah Solusi Edisi 35. Surabaya: Majalah Solusi .
Faure, M. 1995. Economic Models of Compensation for Damage Caused by Nuclear Accidents: Some Lessons for the Revision of the Paris and Vienna Conventions . European Journal of Law and Economics. 2: 21-43.

Foucault, M. 1984. Truth and Method. Dalam P. Rabinow (Penyunt.), The Foucault Reader. New York: Pantheon Books.

Foucault, M. 1988. Technologies of The Self: A Seminar with Michel Foucault. (L. H. Martin, Penyunt.) Massachusetts: University of Massachusetts Press.

Foucault, M. 1997. The Politics of Truth. New York : Semiotext.

Foucault, M. 2004. The Birth of Biopolitics, Lectures at The College de France 1978-1979. (M. Senelert, Penyunt.) Hampshire: Palgrave Macmillan.

Haryatmoko. 2010. Kekuasaan-Pengetahuan Sebagai Rezim Wacana Sejarah Seksualitas: Sejarah Pewacanaan Seks \& Kekuasaan Menurut Foucault. Makalah Seri Kuliah Umum. Juni 2010. Jakarta: Salihara.

Karib, F. 2012. Programming Disaster; Switching Network, Village Politics and Exclusion Beyond Lapindo Mudflow. Passau: Tesis, Southeat Asian Study, Passau University.

Kreps, G. A., \& Drabek, T. E. 1996. Disaster Are Nonroutine Social Problems. International Journal of Mass Emergencies and Disaster.14(2):133.

Kriyantono, R. 2011. A Critical Ethnography of Crisis Management Dealing with a Mudflow Crisis in Sidoarjo, Indonesia. School of Communications and Arts Edith Cowan University.

Kriyantono, R. 2012. Measuring a Company Reputation in a Crisis Situation: An Ethnography Approach on the Situational Crisis Communication Theory. International Journal of Business and Social Science. 3(9). 
Kurtcu, E. 2014. Corporate Social Responsibility in The Realm of Neo-Liberal Art of Governing. Diambil kembali dari GeT MA Working Paper No. 3, Departemen of Social Sciences, Humboldt-Universität zu Berlin: http:/ / edoc.hu-berlin.de/series / getmaseries

Lemke, T. 2001. The Birth of Bio-Politics: Michel Foucault's lecture at the Collège de France on Neo-Liberal Governmentality. Economy and Societ., 30(2): 190-207.

Mallin, C. A. (Penyunt.). 2009. Corporate Social Responsibility: A Case Study Approach. Massachusetts: Edward Elgar Publishing, Inc.

Mazzini, A. H., G. Svensen., G. Akhmanov., S. Aloisi., A. Planke., \& Istadi. 2007. Triggering and Dynamic Evolution of The Lusi Mud Volcano, Indonesia. Journal ScienceDirect, Earth and Planetary Letter. 261: 375-388.

McMichael, H. 2009. The lapindo Mudflow Disaster: Environmental, Infrastructure and Economic impact. Bulletin of Indonesian Economic Studies, 45(1): 73-83.

Novenanto, A. 2009. Mediated Disaste The Role of Alternative and Mainstream Media in The East Java Mud Volcano Disaster. Leiden: Department of Cultural Anthropology and Development Sociology, University of Leiden.

Oliver-Smith, A. 1991. Successes and Failures in Post-Disaster Resettlement. The Journal of Disaster and Studies and Management. 15(1).

Putri, T. A., \& Yudhastuti, R. 2013. Kandungan Besi (Fe) Pada Air Sumur dan Gangguan Kesehatan Masyarakat di Sepanjang Sungai Porong Desa Tambak Kalisogo Kecamatan Jabon Sidoarjo. Surabaya: Departemen Kesehatan Lingkungan, Fakultas Kesehatan Masyarakat, Universitas Airlangga.
Republik-Indonesia. 2007. Peraturan Presiden Republik Indonesia Nomor 14 Tahun 2007 Tentang Badan Penanggulangan Lumpur Sidoarjo. Jakarta: Sekretariat Negara.

Republik-Indonesia. 2007. Undang-Undang Republik Indonesia Nomor 24 Tahun 2007 tentang Penanggulangan Bencana. Jakarta: Sekretariat Negara.

Republik-Indonesia. 2007. Undang-Undang Republik Indonesia Nomor 25 Tahun 2007 tentang Penanaman Modal. Jakarta: Sekretariat Negara.

Richards, J. R. 2011. Report Into The Past, Present and Future Social Impacts of Lumpur Sidoarjo. Sidoarjo: Humanitus Sidoarjo Fund.

Santoso, V. Mei-Juni 2007. Harga Industrialisasi Sektor Migas, Semburan Lumpur LAPINDO Sebagai Potret Kelemahan Negara dalam Menghadapi Korporasi Ekstratif Hidrokarbon. Majalah CSR Review Edisi X/ Tahun2/

Schiller, J. A., Lucas, P., \& Sulistiyanto. 2008. Learning from The East Java Mudflow: Disaster Politics in Indonesia. Cornell: Cornell South East Asia Program.

Sugarman, S. D. 2006. Roles of Government in Compensating Disaster Victims. Issues in Legal Scholarship, Manuscript 1093, 1-33.

Surat Lapindo Brantas Inc. 4 Desember 2006. kepada Tim Nasional Penanggulangan Semburan Lumpur Sidoarjo.

Utomo, P. W. 2009. Menggapai Mimpi yang Terus Tertunda: Menelusuri Proses "Ganti Rugi" Terhadap Penyintas Lumpur Lapindo. Jurnal Disastrum. 1(1): 27-45.

Utomo, P. W., \& B. Batubara. 2009. Skema Ganti Rugi Terhadap Penyintas Lumpur Panas Di Sidoarjo (Kajian di Desa Ketapang dan Besuki Timur). Laporan Penelitian. Surabaya. 
Walhi Jawa Timur. 2008. Logam Berat dan PAH Dalam Air dan Lumpur Lapindo Riset Awal Walhi Jawa Timur 2007-2008. Sidoarjo: Walhi Jawa Timur.
Welker, M. 2009. Corporate Security Begins in The Community: Mining, The Corporate Social Responsibility Industry, and Environmental Advocacy in Indonesia. Cultural Anthropology. 24(1): 142-179. 